\title{
Effects of herbal growth promoter feed additive in fish meal on the performance of Nile Tilapia (Oreochromis niloticus (L.))
}

Adekunle Ayokanmi DADA

Department of Fisheries and Aquaculture Technology Federal University of

Technology, Akure, Ondo State Nigeria

e-mail: dadaayokanmi@yahoo.com

\begin{abstract}
The effect of dietary herbal powder (superliv $^{\circledR}$ ) on growth and body composition was investigated in Oreochromis niloticus. Fingerlings of about $5.24 \pm$ $0.60 \mathrm{~g}$ were fed diets supplemented with four concentrations $(2.5,5.0,7.5$ and $10 \mathrm{~g}$ $\mathrm{kg}^{-1}$ ) of herbal powder for eight weeks. Survival, specific growth rate, feed efficiency, proximate composition and haematological parameters were higher in fish given herbal diets than fish given the control diet without herbs. The highest specific growth rate $\left(1.33 \pm 0.03 \% \mathrm{day}^{-1}\right)$ and best food conversion ratio $(0.85 \pm 0.03)$ were obtained in the $10 \mathrm{~g} \mathrm{~kg}^{-1}$ herb meal diet treatment. Protein efficiency ratio and feed efficiency were higher in fish fed with herbs and lowest in the control. No differences occurred in fish carcass protein or ash content among the treatments $(p>0.05)$. These results reveal that medicinal herbs in diets enhance growth, feed utilisation and survival of $O$. niloticus fingerlings.
\end{abstract}

Keywords: blood parameters, feed utilisation, growth promoter, rearing period

\section{INTRODUCTION}

There is large number of feed additives available to improve fish growth performance. Some of these additives used in feed mill are chemical products especially hormones and antibiotics which may cause unfavourable side effects. The use of antibiotic growth promoters (AGPs) as feed additives in the aquaculture industry has been criticised by government policies and consumers because of possible development of microbial resistance to these products and their potential harmful effects on human health (Baruah et al. 2008). World Health Organization encourages using of medicinal herbs and plants to substitute or minimize the use of chemicals through the global trend to go back to the nature. Attempts to use the natural materials such as medicinal plants could be widely accepted as feed additives to enhance efficiency of feed utilization and animal productive performance (Levic et al. 2008).

Platel et al. (2002) found that medicinal herbs are desirable for stimulating digestion, and had the highest stimulatory influence particularly on bile secretion and pancreatic enzymes activity. In other way, olfactory feed ingredients enhance growth through their ability to act as feeding enhancers for fish to eat more feed than in normal (Adams 2005). With the shift away from synthetic drugs, the use of medicinal herbs as an alternative for antibiotic growth- promoters in fish is becoming acceptable (Adedeji et al. 2008).

Nile tilapia (O. niloticus) is a well-known tropical food fish native to Africa. $O$. niloticus are principally herbivorous, although occasionally omnivorous. The fish is an efficient converter of waste foodstuff and appears to thrive well on artificial 
supplemental feed (Omoregie et al. 2009). Tilapia farming is socially more acceptable and technically and economically more viable and sustainable. Tilapia culture is a profitable enterprise and even small farmers of Nigeria can afford to culture tilapia to augment their income. Tilapia is consumed by poor people as it is relatively low priced commodity. The objective of this study was to determine the effect of dietary supplementation of commercial herbal growth promoter superliv ${ }^{\circledR}$ on growth, feed utilisation and haematological parameters of $O$. niloticus fingerlings.

\section{MATERIALS AND METHODS}

\section{Formulation of experimental diets}

Superliv ${ }^{\circledR}$ herbal growth promoter powder was obtained from animal care company, Nigeria. Amounts of 0 (control), 2.5, 5.0, 7.5 and $10.0 \mathrm{~g} \mathrm{~kg}^{-1}$ of superliv ${ }^{\circledR}$ powder were taken and mixed with a basal feed (40\% crude protein), comprising standard amounts of fish meal, yellow maize, soy bean meal, blood meal, fish oil, vegetable oil, vitamin premix and starch, formulated according to Fagbenro and Adebayo (2005). All dietary ingredients were milled to a $3 \mathrm{~mm}$ particle size. The ingredients were thoroughly mixed in a Hobbart A-2007 pelleting and mixing machine (Hobart Ltd, London, UK) to obtain a homogeneous mass, and cassava starch was added as a binder. The resultant mash was then pressed without steam through a mixer with a $0.9 \mathrm{~mm}$ die. The pellets were dried at ambient temperature $\left(27-30{ }^{\circ} \mathrm{C}\right)$ and stored at $-20{ }^{\circ} \mathrm{C}$ in a refrigerator. The diets were analyzed for proximate composition, including crude protein, crude lipid, crude fibre, ash and moisture (Table 1).

Table 1: Ingredients in and proximate composition $(\mathrm{g})$ of experimental diets D1 to D5. CP = crude protein, DM = dry matter

\begin{tabular}{|c|c|c|c|c|c|}
\hline \multicolumn{6}{|c|}{ Dietary treatment } \\
\hline Ingredient & D1 & D2 & D3 & D4 & D5 \\
\hline Fish meal $(72 \%)$ & 150 & 150 & 150 & 150 & 150 \\
\hline Yellow maize & 250 & 250 & 250 & 250 & 250 \\
\hline Soybean meal & 450 & 450 & 450 & 450 & 450 \\
\hline Fish oil & 40 & 40 & 40 & 40 & 40 \\
\hline Vegetable oil & 60 & 60 & 60 & 60 & 60 \\
\hline Vitamin premix & 30 & 30 & 30 & 30 & 30 \\
\hline Binder (starch) & 20 & 20 & 20 & 20 & 20 \\
\hline Superliv $\AA(\mathrm{g} / \mathrm{kg}$ feed $)$ & 0.0 & 2.5 & 5.0 & 7.5 & 10.0 \\
\hline \multicolumn{6}{|c|}{ Proximate composition (\% DM) } \\
\hline Moisture & 7.10 & 8.18 & 8.14 & 8.20 & 8.05 \\
\hline Crude protein & 31.30 & 30.30 & 28.70 & 28.70 & 29.80 \\
\hline Crude lipid & 13.26 & 13.74 & 13.65 & 13.75 & 14.25 \\
\hline Crude fibre & 6.24 & 5.88 & 6.12 & 5.12 & 4.35 \\
\hline Ash & 12.15 & 12.06 & 12.00 & 11.88 & 10.88 \\
\hline
\end{tabular}

Vitamin premix - A Pfizer livestock product containing the following per $\mathrm{kg}$ of feed: $\mathrm{A}=4500 \mathrm{I}$. U, D $=11252$

I.U, $\mathrm{E}=71 \mathrm{I} . \mathrm{U}, \mathrm{K}_{3=} 2 \mathrm{mg}, \mathrm{B}_{12}=0.015 \mathrm{mg}$, panthothenic acid $=5 \mathrm{mg}$, nicotinic acid $=14 \mathrm{mg}$, folic acid $=0.4 \mathrm{mg}$, biotin $=0.04 \mathrm{mg}$, choline $=150 \mathrm{mg}$, cobalt $=0.2 \mathrm{mg}$, copper $=4.5 \mathrm{mg}$, iron $=21 \mathrm{mg}$, manganese $=20 \mathrm{mg}$, iodine $=$ $0.6 \mathrm{mg}$, selenium $=2.2 \mathrm{mg}$, zinc $=20 \mathrm{mg}$, antioxidant $=2 \mathrm{mg}$

\section{Experimental procedure}

Three hundred farm-raised O.niloticus fingerling siblings (mean mass $5.24 \pm$ $0.60 \mathrm{~g})$ were acclimated to laboratory conditions for 14 days before distributed randomly into the 15 tanks (20 fish tank ${ }^{-1}$ ) representing four dietary treatments $(2.5$, 5.0, 7.5 and $10.0 \mathrm{~g} \mathrm{~kg}^{-1}$ of superliv ${ }^{\circledR}$ powder $)$ and a control $\left(0 \mathrm{~g} \mathrm{~kg}^{-1}\right.$ of superliv ${ }^{\circledR}$ powder) (Table 1). Fishes were fed at $5 \%$ of their body weight (bw) per day in three equal meals, every five hours between 08:00 and 18:00. All fishes were weighed and 
counted fortnightly and feeding rates were adjusted accordingly. At the end of the experimental period the following growth and feed utilisation indices were calculated: weight gain (WG), specific growth rate (SGR), food conversion ratio (FCR), food conversion efficiency ratio (FCE) and protein efficiency ratio (PER) using the following formulae:

$\mathrm{WG}=$ final average weight $(\mathrm{g})-$ initial average weight $(\mathrm{g})$;

SGR $(\% \mathrm{~d}-1)=100 \times(\ln W \mathrm{t}-\ln W 0) / t$

Where: $W t$ and $W 0$ represent final and initial body weights of fish, respectively, and $t$ represents the duration of the feeding trial;

FCR = dry weight of feed (g) / wet weight gain by fish (g); and

$\mathrm{PER}=$ wet weight gain by fish $(\mathrm{g}) /$ protein intake $(\mathrm{g})$

Where: protein intake $(\mathrm{g})=$ protein $(\%)$ in feed $\times$ total weight $(\mathrm{g})$ of diet consumed $/$ 100.

FCE $=$ weight gain $(\mathrm{g}) /$ dry weight of food consumed $(\mathrm{g}) \times 100$

Water temperature, $\mathrm{pH}$ and dissolved oxygen concentration were routinely monitored in all tanks. At the beginning and end of the feeding trial, pooled samples of 15 fingerlings were analysed for carcass composition using AOAC (1997) procedures. Twelve fishes (four fishes per replicate) were used for blood analysis and $5 \mathrm{ml}$ blood samples from each treatment were collected by cardiac puncture using 5 $\mathrm{ml}$ disposable syringes, into treated Bijou bottles. The blood was stored at- $40{ }^{\circ} \mathrm{C}$ prior to analysis. The blood analysis followed the methods described by Svobodova et al. (1991).

\section{Statistical analysis}

Analysis of variance (ANOVA) was used at 95\% significance level to test for significant differences between the various treatment means obtained for the growth, feed utilisation, carcass composition and haematological parameters. Tukey's multiple range test was used to determine which pairs of the treatment means differed significantly (Zar, 1996).

\section{RESULTS}

Data on growth performance of the fish during the experiment are shown in Table 2. All fish fed actively and appeared healthy. Survival of the fish during the experiment ranged from $50.0 \%$ to $83.3 \%$ as shown in Fig. 1. There were improvements in the growth responses of fish fed on superliv ${ }^{\circledR}$ powder meal. The best growth response was achieved at $5.0 \mathrm{~g} \mathrm{~kg}^{-1}$ of superliv ${ }^{\circledR}$ powder while the slowest growth was obtained in the fish fed the control diet D1 (Table 2). However, there were no significant differences in growth performance across the different superliv ${ }^{\circledR}$ powder concentrations $(P<0.05)$.

Table 2: Mean growth performance and feed utilisation of $O$. niloticus fingerlings fed experimental diets D1 to D5 for 56 days.

\begin{tabular}{|l|l|l|l|l|l|}
\hline Parameter & D1 (Control) & \multicolumn{1}{|c|}{ D2 } & D3 & D4 & D5 \\
\hline Initial mean weight $(\mathrm{g})$ & $5.00(0.00)$ & $5.00(0.00)$ & $5.50(0.00)$ & $5.20(0.00)$ & $5.50(0.00)$ \\
\hline Final mean weight $(\mathrm{g})$ & $8.79(0.10)^{\mathrm{a}}$ & $9.22(0.24)^{\mathrm{a} b}$ & $9.97(0.23)^{\mathrm{b} c}$ & $10.48(0.11)^{\mathrm{c}}$ & $11.57(0.21)^{\mathrm{d}}$ \\
\hline Weight gain $(\mathrm{g})$ & $3.79(0.99)^{\mathrm{a}}$ & $4.22(0.12)^{\mathrm{a} b}$ & $4.47(0.23)^{\mathrm{a} b}$ & $5.28(0.13)^{\mathrm{b}}$ & $6.07(0.21)^{\mathrm{c}}$ \\
\hline PER & $2.47(0.13)^{\mathrm{a}}$ & $3.05(0.16)^{\mathrm{bc}}$ & $2.81(0.93)^{\mathrm{a} b}$ & $3.38(0.13)^{\mathrm{c}}$ & $3.56(0.12)^{\mathrm{c}}$ \\
\hline FE & $1.01(0.20)^{\mathrm{a}}$ & $1.09(0.47)^{\mathrm{a}}$ & $1.06(0.40)^{\mathrm{a}}$ & $1.25(0.20)^{\mathrm{b}}$ & $1.33(0.32)^{\mathrm{b}}$ \\
\hline FCR & $1.22(0.64)^{\mathrm{a}}$ & $0.99(0.52)^{\mathrm{bc}}$ & $1.07(0.37)^{\mathrm{ab}}$ & $0.89(0.06)^{\mathrm{c}}$ & $0.85(0.30)^{\mathrm{c}}$ \\
\hline SGR $(\%$ day-1) & $81.84(4.64)^{\mathrm{a}}$ & $101.11(5.46)^{\mathrm{bc}}$ & $93.08(3.09)^{\mathrm{a} b}$ & $111.94(1.08)^{\mathrm{c}}$ & $118.02(4.07)^{\mathrm{c}}$ \\
\hline
\end{tabular}

Values in parentheses are standard errors of means. Means in a given row with the same superscript letter were not significantly different at $p<0.05$. SGR $=$ specific growth rate, PER $=$ protein efficiency ratio, $\mathrm{FCR}=$ feed conversion ratio, $\mathrm{FE}=$ feed efficiency 


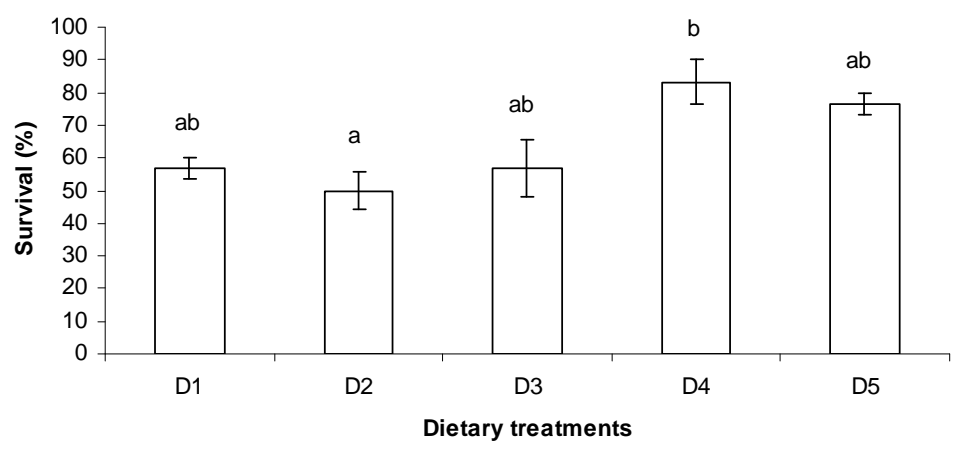

Fig.1. Effect of herbal growth promoter "Superliv®" ${ }^{\circledR}$ "on percentage survival of Oreochromis niloticus. $\mathrm{D} 1=0, \mathrm{D} 2=2.5, \mathrm{D} 3=5.0, \mathrm{D} 4=7.5$ and D5 is 10.0 rates of Superliv ${ }^{\circledR}$ in feed. The values with the different letter are significantly different $(\mathrm{P}<0.05)$.

There were greater improvements in the feed conversion ratio (FCR) of fish fed on superliv ${ }^{\circledR}$ powder meal than the control fish $(P<0.05)$. The average FCRs were $0.99,1.07,0.89$ and 0.85 for diets D2, D3, D4 and D5 respectively.

The PER was 3.05, 2.81, 3.38 and 3.56 for the fish fed diets D2, D3, D4 and D5 respectively $(P<0.05)$. The results of feed efficiency followed the same trends as FCR and PER, which were found to be 101.11, 93.08, 111.94 and 118.02 for fish fed diets D2, D3, D4 and D. Fish fed on superliv ${ }^{\circledR}$ powder meal had a significantly $(p<$ 0.05) higher protein content than fish fed the control diet. The body composition values are given in Table 3.

Table 3: Chemical composition of whole body of $O$. niloticus fingerlings fed experimental diets D1 to D5 (wet basis).

\begin{tabular}{|l|l|l|l|l|l|}
\hline \multicolumn{7}{|c|}{ Dietary treatment } \\
\hline Composition (\%) & D1 (Control) & D2 & D3 & D4 & D5 \\
\hline Moisture & $12.57(0.17)^{\mathrm{ab}}$ & $13.79(0.06)^{\mathrm{b}}$ & $11.11(0.88)^{\mathrm{a}}$ & $12.87(0.23)^{\mathrm{a} b}$ & $12.52(0.02)^{\mathrm{a}}$ \\
\hline Crude protein & $57.87(0.45)^{\mathrm{a}}$ & $59.52(0.29)^{\mathrm{a}}$ & $58.10(0.31)^{\mathrm{a}}$ & $59.48(0.23)^{\mathrm{a}}$ & $58.55(0.27)^{\mathrm{a}}$ \\
\hline Crude lipid & $5.88(0.42)^{\mathrm{a}}$ & $5.38(0.34)^{\mathrm{a}}$ & $7.13(0.46)^{\mathrm{a}}$ & $5.34(0.16)$ & $6.08(0.86)^{\mathrm{a}}$ \\
\hline Ash & $23.24(0.55)^{\mathrm{a}}$ & $21.01(0.58)^{\mathrm{a}}$ & $23.04(0.41)^{\mathrm{a}}$ & $0.62(0.08)^{\mathrm{a}}$ & $21.19(0.53)^{\mathrm{a}}$ \\
\hline NFE & $0.44(0.16)^{\mathrm{a}}$ & $0.28(0.11)^{\mathrm{a}}$ & $0.60(0.31)^{\mathrm{a}}$ & $22.86(0.98)^{\mathrm{a}}$ & $0.73(0.10)^{\mathrm{a}}$ \\
\hline
\end{tabular}

Means in a given row with the same superscript letter were not significantly different at $p<0.05$. Values in parentheses are standard errors of means NFE $=$ Nitrogen free extract

The haematological parameters of O. niloticus (Table 4) showed significant differences $(p \geq 0.05)$ in red blood cell, haemoglobin or pack cell volume in all the treatments. There were significant differences $(p<0.05)$ in the haematological parameters of fish fed on superliv ${ }^{\circledR}$ powder. Fishes fed on diets supplemented with superliv ${ }^{\circledR}$ powder meal had significantly higher $(p<0.05)$ white blood cell counts than the control.

Table 4: Some haematological characteristics of $O$. niloticus fed the experimental diets.

\begin{tabular}{|l|l|l|l|l|l|}
\hline \multicolumn{7}{|c|}{ Dietary treatment } \\
\hline Blood parameter & D1 & D2 & D3 & D4 & D5 \\
\hline $\mathrm{PCV}(\%)$ & $11.0(0.50)^{\mathrm{d}}$ & $8.00(0.50)^{\mathrm{bc}}$ & $5.00(0.46)^{\mathrm{a}}$ & $7.00(0.35)^{\mathrm{ab}}$ & $10.00(0.22)^{\mathrm{cd}}$ \\
\hline $\mathrm{Hb}(\mathrm{g} / 100 \mathrm{ml})$ & $3.70(0.10)^{\mathrm{c}}$ & $2.70(0.05)$ & $3.70(0.05)^{\mathrm{a}}$ & $2.31(0.13)^{\mathrm{b}}$ & $1.20(0.02)^{\mathrm{cd}}$ \\
\hline $\mathrm{WBC}\left(\times 10^{3} / \mu \mathrm{l}\right)$ & $5600(40.0)^{\mathrm{a}}$ & $6900(12.0)^{\mathrm{c}}$ & $9800(40.0)^{\mathrm{e}}$ & $9500(44.0)^{\mathrm{d}}$ & $64000(20.0)^{\mathrm{b}}$ \\
\hline $\mathrm{RBC}\left(\times 10^{6} / \mu \mathrm{l}\right)$ & $1.40(0.50)^{\mathrm{d}}$ & $1.00(0.10)^{\mathrm{bc}}$ & $0.60(0.05)^{\mathrm{a}}$ & $0.80(0.04)^{\mathrm{ab}}$ & $3.32(0.07)^{\mathrm{b}}$ \\
\hline
\end{tabular}

Means in a given row with the same letter were not significantly different at $p<0.05$. Values in parentheses are standard errors of means. $\mathrm{PCV}=$ packed cell volume, $\mathrm{H} \mathrm{b}=$ haemoglobin estimation, $\mathrm{WBC}=$ white blood cell count, $\mathrm{RBC}=$ red blood cell count. 
The water quality parameters measured were within the desired range, dissolved oxygen $4.0-4.2 \mathrm{mg} \mathrm{l}^{-1}$, $\mathrm{pH}, 6.96-7.00$ and temperature, $26.2-27.2^{\circ} \mathrm{C}$.

\section{DISCUSSION}

The results suggest that dietary superliv ${ }^{\circledR}$ powder at all concentrations promoted the growth of $O$. niloticus fingerlings. These results showed that the superliv ${ }^{\circledR}$ powder meal treatment enhances nutrient utilisation, which is reflected in improved weight gain, FCR, PER, PE and SGR. Generally, high feed conversion ratio values were obtained in all treatments, but the poorest occurred in D1 $\left(0 \mathrm{~g} \mathrm{~kg}^{-1}\right.$ of superliv ${ }^{\circledR}$ powder meal) (Table 2). Although better FCR values were obtained in the superliv ${ }^{\circledR}$ powder dietary treatments compared to the control, there were significant $(P<0.05)$ differences among the treatment means. Medicinal herb in diets also promoted growth and feed conversion efficiency in shrimp (Olmedo Sanchez et al 2009). Similar results were reported by Turan (2006) who used the medical herb red clover Trifolium pratense as a growth-promoting agent for tilapia O. aureus. Zakes et al. (2008) also reported that juvenile pike perch (Sander lucioperca) fed on diets supplemented by medicinal plants exhibited faster growth than those fed with the control diet. Similar results were reported for using medicinal plants as growth-promoting agents for common carp Cyprinus carpio (Yilmaz et al. 2006), guppy Poecilia reticulata (Cek et al. 2007a), the cichlid Cryptoheros nigrofasciatus (Cek et al. 2007b), and red sea bream Pagrus major (JI et al. 2007).

Kim et al. (1998) suggested that unknown factors in various medicinal herbs led to favourable results in fish growth trials. The present findings may indicate that the presence of bioflavonoids in superliv ${ }^{\circledR}$ powder stimulate growth in fish. In addition, bioflavonoids are plant chemicals with estrogenic activity, and studies have shown that estrogen promotes growth in common carp (Kocour et al. 2005). Therefore, superliv ${ }^{\circledR}$ powder that promotes growth performance in the O. niloticus should be tested for its efficacy to induce efficient and economical propagation in other fishes. The best feed utilisation values observed with diets supplemented with superliv ${ }^{\circledR}$ powder meal suggested that the addition of superliv ${ }^{\circledR}$ powder improved feed utilisation.

The body composition values obtained in this study were similar to those reported by Diab et al. (2002), Lara-Flores et al. (2003) and Hamid and Mohamed (2008). White blood cell counts were significantly higher $(P<0.05)$ in fish fed diets including 2.5, 5.0, 7.5 and $10.0 \mathrm{~g} \mathrm{~kg}^{-1}$ of superliv ${ }^{\circledR}$ powder. Differences in blood parameters of fish in this study could therefore be ascribed to differences in the dietary inclusions of superliv ${ }^{\circledR}$ powder in the diets.

\section{CONCLUSION}

Results from the aforementioned study indicate promising potential and compel aqua feed manufacturers to consider using medicinal herbs in their diets. The use of herbs, especially of superliv ${ }^{\circledR}$ in tilapia, will be an efficient tool to achieve sustainable, economical, and safe fish production. 


\section{REFERENCES}

Adams C. (2005). Nutrition-based health. Feed internat. 2: 25-28.

Adedeji O.S., Farinu G.O., Olayemi T.B., Ameen S.A. and Babatunde G.M. (2008). The use of bitter kola (Garcinia kola) dry seed powder as a natural growth promoting agent in broiler chicks. Res. J. Poultry Sci.2: 78-81.

AOAC (Association of Official Analytical Chemists). (1997). Official methods of analysis of AOAC International (16th edn). Arlington,Virginia:

Baruah K., Norouzitallab P., Debnath D., Pal A .K. and Sahu N.P. (2008). Organic acids as non-antibiotic nutraceuticals in fish and prawn feed. Aquacult Health Internat.12: 4-6.

Cek S., Turan F. and Atik E. (2007a). The effects of gokshura, Tribulus terrestris, on sex differentiation of guppy, Poecilia reticulata. Pak. J. Biol.Sci.10: 718-725.

Cek S., Turan F. and Atik E. (2007b). Masculinization of convict cichlid (Chichlasoma nigrofasciatum) by immersion in Tribulus terrestris extract. Aquacult Internat.15: 109-119.

Diab A.S., El-Nagar O.G. and Abd-El-Hady M.Y. (2002). Evaluation of Nigella sativa L. (black seeds, Baraka), Allium sativum (garlic) and Biogen as feed additives on growth performance and immunostimulants of Oreochromis niloticus fingerlings. Suez Canal Vet. Med. J. 2: 745-753.

Fagbenro O.A. and Adebayo O.T. (2005). A review of the animal and aquafeed industries in Nigeria. In: Moel J, Halwart M (eds), A synthesis of the formulated animal and aquafeed industry in sub-Saharan Africa. CIFA Occasional Paper No. 26.

Hamid E.B. and Mohamed K.A. (2008). Effect of using probiotics as growth promoters in commercial diets for monosex Nile tilapia (Oreochromis niloticus) fingerlings. In: Elghobashy H., Fltzsimmons K., Dlab A.S. (eds), Proceedings of the Eighth International Symposium on Tilapia in Aquaculture, 12-14 October 2008, Cairo, Egypt. pp 241-252.

Ji S., Takaoka O., Jeong G., Lee S., Ishumaru K., Seoka M. and Takii K. (2007). Dietary medicinal herbs improve growth and some non-specific immunity of red sea bream Pagrus major.Fish Sci.73(1): 63-69.

Kim D.S., Noah C.H., Jung S.W. and Jo J.Y. (1998). Effect of Obosan supplemented diet on growth, feed conversion ratio and body composition of Nile tilapia, Oreochromis niloticus. J. Aquacul.11: 83-90.

Kocour M., Lynhard O., Gela D. and Rodina M. (2005). Growth performance of allfemale and mixed-sex common carp, Cyprinus carpio L. population in central European climatic conditions. J.World Aquacult. Soc.36: 103-113.

Lara-Flores M., Olvera-Novoa M.A., Guzman-Mendez B.E. and López-Madrid W. (2003). Use of the bacteria Streptococcus faecium and Lactobacillus acidophilus, and the yeast Saccharomyces cerevisiae as growth promoters in Nile tilapia (Oreochromis niloticus). Aquacul.216: 193-201.

Levic J., Sinisa M., Djuragic O. and Slavica S. (2008). Herbs and organic acids as an alternative for antibiotic- growth-promoters. Archiva Zootechnica 11: 5-11.

Olmedo sanchez, J.A, Curiel Flores, A, Orozco, J.R. (2009). The effect of a herbal growth promoter feed additive on shrimp performance. Res. J. Biol.Sci. 4: 10221024.

Omoregie E., Igoche L., Ojobe T.O., Absalom K.V. and Onusiriuka K.V. (2009). Effect of varying levels of sweet potato (Ipomea batatas) peels on growth, feed 
utilization and some biochemical responses of the cichlid (Oreochromis niloticus). Afric. J. Food. Agri. Nutr.and Dev. 9: 700-712.

Platel K., Rao A., Saraswahi G. and Srinivasan K. (2002). Digestive stimulant action of three indian spice mixes in experimental rats. Die. Nahrung 46: 394-398.

Svobodova Z., Ravds D. and Palackova J. (1991). Unified methods of haematological examination of fish. Arlington, Virginia: Research Institute of Fish Culture and Hydrobiology.

Turan F. (2006). Improvement of growth performance in Tilapia (Oreochromis niloticus Linnaeus) by supplementation of red clover (Trifolium pretense) in diets. Bamidgeh 58: 34-38.

Yilmaz E., Genc M.A., Cek S., Mazlum Y. and Genc E. (2006). Effects of orally administered Ferula coskunii (Apiaceae) on growth, body composition and histology of common carp, Cyprinus carpio. J. Anim.Vet. Adv. 5: 1236-1238.

Zakes Z., Kowalska A., Demska-Zakes K., Jeney G. and Jeney Z. (2008). Effect of two medicinal herbs (Astragalus radix and Lonicera japonica) on the growth performance and body composition of juvenile pike perch (Sander lucioperca). Aquacult res., 39:1149-1160. Zar J.H. (1996). Biostatistical analysis. $3^{\text {rd }}$ Edition. Prentice-Hall, Upper Saddle River, New jersey, US: 383. 